\title{
Development Perspectives of Labourers in Unorganized Sector of Urban India - An Empirical Study
}

\author{
Dr.Vikram K. Joshi \\ Assistant Professor - DMT, Shri Ramdeobaba College of Engineering and Management, RamdeoTekdi, \\ Gittikhadan, Katol Road, Nagpur, Maharashtra 440013 \\ Email:vikramkjoshi@gmail.com
}

\section{Received: $20^{\text {th }}$ September 2018, Accepted: $11^{\text {th }}$ October 2018, Published: $31^{\text {st }}$ October 2018}

\begin{abstract}
India witnessed reasonably high economic growth over the last decade, but a large part of the population, particularly unorganized sector is continued to suffer economic exclusions even today in the era of globalization. Nagpur city in India in the recent years has gained an identity as a fast growing city. Resultantly, the increase in the population of unorganized sector is significantly apparent. Hence the study of this kind related to unorganized sector of Nagpur will prove useful to understand the economic development perspectives of urban poor population belonging to unorganized sector in India.

For the study a sample survey of selected households of size 103 belonging to unorganized sector in Nagpur city is conducted. The study analyzes the economic development perspectives of urban poor in unorganised sector of Nagpur city along with identifying the significant attributes influencing the perception of the households for evaluation of their economic status and various development issues which needs immediate attention.
\end{abstract}

\section{Keywords \\ Unorganised Sector, Urban Poor, Economic Development}

\section{Introduction}

India's economic growth remained significantly high over the last decade, but at the same time economic inequalities also grew sharply and the struggle for survival for those at the bottom became bad to worse as the large part of population still remained economically excluded. The people belonging to unorganized sector are still facing difficulty in protecting their livelihoods. Thus, inclusive development has always remained a major concern in the planning process. Inclusive development is viewed in terms of economic inclusion reflected in poverty reduction, better health care, increased access to education and improved access to basic amenities, etc. According to Amartya Sen (2001), development is about creating freedom for people and removing obstacles to greater freedom, and hence to development, includes poverty, lack of economic opportunities, corruption, poor governance, lack of education and lack of health. Thus, as pointed out by Dogra (2014), economic planning must ensure the availability of goods and services which meet the basic needs of the people, protect likelihoods, keep unemployment at low levels and provide essential infrastructure.

Thus, in country like India where a large part of the population, particularly unorganized sector continued to suffer economic exclusions even today in the era of globalization due to lack of development opportunities and necessary infrastructure needed for effective economic participation, it is necessary to think about the economic development perspectives of this very important sector of the economy.

According to NCEUS report 2009, unorganized workers consist of those working in the unorganized sector or households, excluding regular workers with social security benefits provided by the employers and the workers in the formal sector without any employment and social security benefits provided by the employers. The term unorganised sector refers to the firms whose activities are not governed by any legal provision or any collective agreements between workers and employers. This includes home-based jobs, self-employment, agricultural work, construction work and a lot of other temporary occupations. As cited by NCEUS report 2009, between the two NSSO rounds 1999-00 and 2004-05, the informal/unorganised workers have increased from $91.5 \%$ to $92.3 \%$. Over the years, the proportion of rural informal sector workers is decreasing and the proportion of urban informal workers is continuously increasing. Thus, it is necessary that the government policies must be directed towards the economic and social upliftment of this sector to enable them to reap the benefits of growth and bring them into the mainstream. Nagpur city in India in the recent years has gained an identity as a fast growing city becoming an employment hub for the inhabitants of nearby towns. Resultantly, the increase in the population of unorganized sector is significantly apparent. It is necessary to ensure a reasonable economic well-being and quality of life for this community as they are the important participants of an economic activity. Hence the study of this kind related to unorganized sector of 
Nagpur will prove useful to understand the economic development perspectives of urban poor population belonging to unorganized sector in India and identify the areas of focus for better implementation of policies for effective participation of this segment in an economic activity. The rest of the paper is organized as below: Section II discusses the Material and Methods; Section III deals with the results and discussions; and Section IV concludes.

\section{Material and Methods Literature Review}

The glimpses of the studies associated with the economic development of the urban poor and slum dwellers working in unorganised sector are provided as below:

Bhat and Yadav (2017) mentioned that in India the informal sector labourers have prominent problems like job security, social security, the stability of living, migration, child labour and exploitation of working women. Hence, government must design a credible comprehensive and workable social security package for unorganized women workers of India as they are the most important participants in the sector.

Zhang and Vanneman (2008) explained that the household fuel-use decision allows us to empirically assess household preference towards the environment and determine how it evolves with increased income.

Sarin and Jain (2009) studied the impact of mobile phones on the social and economic life of urban labourers and commented that the majority of the respondents believe that the use of mobile has led to an improvement in their economic situation and these benefits are greater than ownership and usage costs.

Sufaira C (2013) and Ray S (2016) mentioned that there exists a need for measures to improve the physical environment of the dwelling places like basic amenities of toilets, proper drainage, sewerage system, adequate water supply and school enrolment and lowering school dropout to increase literacy rate.

Karn S.K, Shigeo Shikura and Harada Hideki (2003) concludes that the needs of the urban poor and their priorities are hierarchial, wherein they first needs approval to stay in the place, i e, securing land and housing and then provision of basic amenities in the order of toilet, water supply, sewage and drainage and so on.

Against this backdrop the present study concentrates on the detailed analysis of economic development of urban poor in unorganised sector of Nagpur city along with identifying the significant attributes influencing the perception of the urban labourers for evaluation of their economic status and various development issues which needs immediate attention.

\section{Methodology \& Data}

As the research is descriptive in nature the study relies on primary data collected from the informal sector workers who are urban poor working in Nagpur city and living mostly in slum areas of Nagpur city during January 2018 to July 2018. The primary data was collected by conducting an interview through a structured questionnaire administered on 103 urban laboureres belonging to informal sector through judgement sampling method. The primary intention of the survey was to observe the economic development perspectives of the urban-poor. The analysis of economic development perspective is done on the basis of two aspects, viz., the factors influencing the perception towards the economic status and the issues critical to better participation in an economic activity. Thus, the questionnaire consisted of questions based on the various factors influencing the perception towards the economic development and the problems faced by the urban poor for their livelihood and economic prosperity. The questionnaires were administered to household head or his close family member.

The sample units selected for the study are the workers belonging to various occupations like labourers, fruits and vegetable sellers, snacks vendors, tea and pan shops, private business persons who are self-employed, auto drivers and rikshaw pullers, road hawkers, etc., whose monthly income is less than Rs. 30,000. The data is analyzed using various statistical graphs and charts and interpretations are made.

For analyzing the significant factors determining the perceptions of the people towards the economic status (whether they are very poor or belonging to middle income group), the stepwise regression analysis is performed using the following regression equation and significant factors influencing the perception were evaluated.

$$
\begin{aligned}
& \mathrm{Y}=\mathrm{a}+\mathrm{b}_{1} \mathrm{X}_{1}+\mathrm{b}_{2} \mathrm{X}_{2}+\mathrm{b}_{3} \mathrm{X}_{3}+\mathrm{b}_{4} \mathrm{X}_{4}+\mathrm{b}_{5} \mathrm{X}_{5}+\mathrm{b}_{6} \mathrm{X}_{6}+\mathrm{b}_{7} \mathrm{X}_{7}+\mathrm{D}_{1} \mathrm{X}_{81}+\mathrm{D}_{2} \mathrm{X}_{82}+\mathrm{D}_{3} \mathrm{X}_{83}+\mathrm{D}_{4} \\
& \mathrm{X}_{84}+\mathrm{D}_{5} \mathrm{X}_{85}+\mathrm{b}_{9} \mathrm{X}_{9} \\
& \text { where, a }- \text { Intercept } \\
& \mathrm{b}_{1}, \ldots \mathrm{b}_{7} \& \mathrm{D}_{\mathrm{i}} \text { are the coefficients of } \mathrm{X}_{1}, \mathrm{X}_{2}, \ldots, \mathrm{X}_{7} \& \mathrm{X}_{8 \mathrm{i}} \text {. } \\
& \quad \mathrm{Y}=\text { Perception of HH member about Economic status (Very Poor }=1 \text {, Poor =2, Lower } \\
& \quad \text { Middle Income Level =3, Middle Income Level }=4 \text { ) } \\
& \quad \mathrm{X}_{1}=\text { Avg. Monthly Income (Less than } 10 \mathrm{~K}=1,10-20 \mathrm{~K}=2,20-30 \mathrm{~K}=3 \text { ) }
\end{aligned}
$$


$\mathrm{X}_{2}=$ Secondary Occupation (Yes $=1, \mathrm{No}=0$ )

$\mathrm{X}_{3}=$ Ownership status of house $($ Owner $=1$, Renter $=0)$

$\mathrm{X}_{4}=$ Nature of House $($ Kaccha $=1$, Semipucca $=2$, Pucca $=3)$

$\mathrm{X}_{5}=$ Household members

$\mathrm{X}_{6}=$ Fuel Consumption $($ Fuel oil $=1$, Fuel wood $=2$, Gas $(L P G)=3$, Induction Stove $=4)$

$\mathrm{X}_{7}=$ Holding account in bank $(\mathrm{Yes}=1, \mathrm{No}=0)$

$\mathrm{X}_{8 \mathrm{i}}=$ Ownership of Assets; $\mathrm{i}=1,2,3,4,5$

$\left(\mathrm{D}_{1}-\right.$ Television $(\mathrm{Yes}=1, \mathrm{No}=0) ; \quad \mathrm{D}_{2}-$ Telephone $(\mathrm{Yes}=1, \mathrm{No}=0)$;

$\mathrm{D}_{3}-$ Mobile Phone $(\mathrm{Yes}=1, \mathrm{No}=0) ; \quad \mathrm{D}_{4}-$ Computer/Laptop $(\mathrm{Yes}=1, \mathrm{No}=0)$;

$\mathrm{D}_{5}-$ Scooter/Motor cycle/Moped $(\mathrm{Yes}=1, \mathrm{No}=0)$ )

$\mathrm{X}_{9}=$ Education Level of Household member

\section{Results and Discussion}

For the purpose of study, a sample of 103 households was selected. The number of members in each household of unorganized sector surveyed is presented in fig 1 given as below:

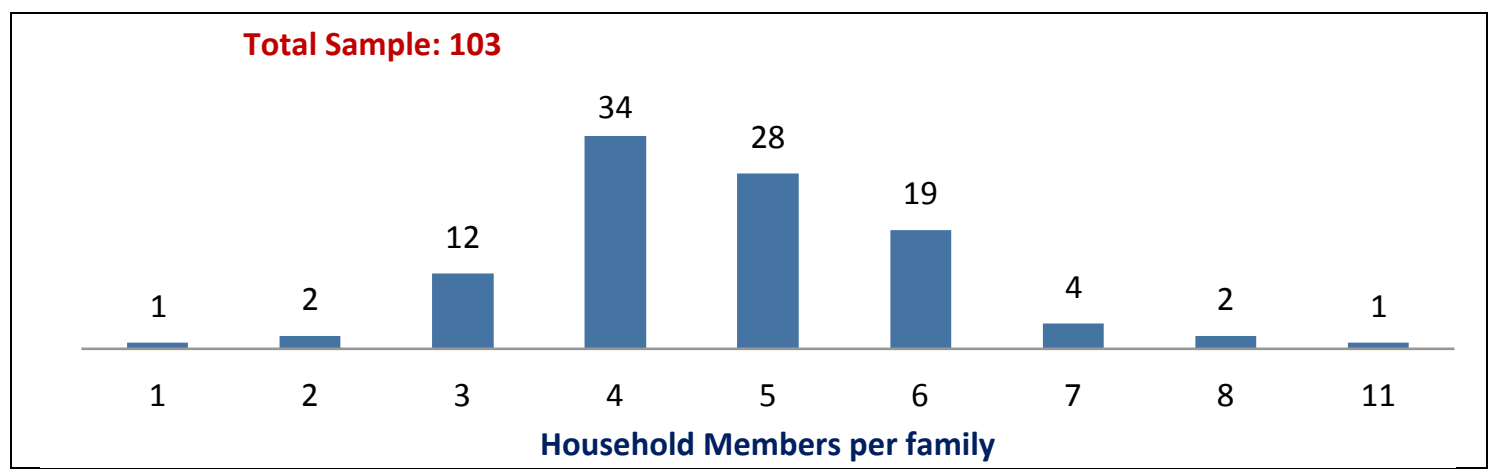

Fig 1: Number of Household Members per Family

From the fig 1, it can be seen that there are 34 families with four members each, followed by 28 families with 5 members each and 19 families with 6 members each. There are 12 families with 3 members each and one household with 1 member and one household with 11 members in an obtained sample. From the shape of the histograms, it seems that the data fulfills the criteria of normality in terms of no. of members per family.

The descriptive statistics with regard to the migration status, average monthly income from primary and secondary sources, no. of members in household, nature and ownership status of house, availability water and electricity, ownership of assets, etc., is presented in table 1 below:

\begin{tabular}{|c|c|c|c|c|}
\hline No. of households & \multicolumn{3}{|l|}{ Total } & 103 \\
\hline \multirow[t]{2}{*}{ Rural Migration to Nagpur } & Total & $\begin{array}{l}\text { Children } \\
\text { Education }\end{array}$ & $\begin{array}{ll}\text { Look for } \\
\text { Work }\end{array}$ & Start New Job \\
\hline & $44(43 \%)$ & $2(2 \%)$ & $36(35 \%)$ & $6(6 \%)$ \\
\hline \multirow[t]{3}{*}{ Average Monthly Income of Households } & \multicolumn{3}{|c|}{$<\operatorname{Rs} 10,000$} & $37(36 \%)$ \\
\hline & \multicolumn{3}{|c|}{ Rs 10,000 - Rs 20,000} & $50(49 \%)$ \\
\hline & \multicolumn{3}{|c|}{ Rs 20,000 - Rs 30,000} & $16(15 \%)$ \\
\hline \multirow{2}{*}{$\begin{array}{l}\text { Household having earnings from } \\
\text { secondary sources }\end{array}$} & \multicolumn{3}{|l|}{ Yes } & $19(18.4 \%)$ \\
\hline & \multicolumn{3}{|l|}{ No } & $84(81.6 \%)$ \\
\hline \multirow[t]{2}{*}{ Ownership status of Households } & \multicolumn{3}{|l|}{ Renter } & $32(31 \%)$ \\
\hline & \multicolumn{3}{|l|}{ Owner } & $71(69 \%)$ \\
\hline Nature of House & \multicolumn{3}{|l|}{ Total } & 103 \\
\hline \multirow[t]{2}{*}{ Pucca } & \multicolumn{2}{|l|}{ Total } & Owner & Renter \\
\hline & \multicolumn{2}{|l|}{$41(40 \%)$} & $33(32 \%)$ & $8(8 \%)$ \\
\hline \multirow[t]{2}{*}{ Semipucca } & \multicolumn{2}{|l|}{ Total } & Owner & Renter \\
\hline & \multicolumn{2}{|l|}{$32(31 \%)$} & $22(21 \%)$ & $10(10 \%)$ \\
\hline Kaccha & \multicolumn{2}{|l|}{ Total } & Owner & Renter \\
\hline
\end{tabular}




\begin{tabular}{|c|c|c|c|c|c|c|}
\hline \multirow{5}{*}{\multicolumn{3}{|c|}{ Domestic Water Resources at Home }} & $30(29 \%)$ & 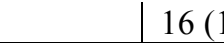 & $5 \%)$ & $14(14 \%)$ \\
\hline & & & \multicolumn{3}{|c|}{\begin{tabular}{|l}
$30(29 \%)$ \\
Interior tap water \\
\end{tabular}} & $41(40 \%)$ \\
\hline & & & \multicolumn{3}{|c|}{ Water Pump/Borewel } & $41(40 \%)$ \\
\hline & & & \multicolumn{3}{|l|}{ Well Water } & $18(17 \%)$ \\
\hline & & & \multicolumn{3}{|l|}{\begin{tabular}{|l|} 
Tanker \\
\end{tabular}} & $3(3 \%)$ \\
\hline \multirow{3}{*}{\multicolumn{3}{|c|}{ Sanitation Facility at Home }} & \multicolumn{3}{|c|}{ Toilet Facility in the Premises } & $82(80 \%)$ \\
\hline & & & \multicolumn{3}{|l|}{ Public Toilets } & $20(19 \%)$ \\
\hline & & & \multicolumn{3}{|l|}{ Open Defecation } & $1(1 \%)$ \\
\hline \multirow{4}{*}{\multicolumn{3}{|c|}{ Waste Water \& Sewage System }} & \multicolumn{3}{|c|}{ Connected to drainage system } & $47(46 \%)$ \\
\hline & & & \multicolumn{3}{|c|}{ Septic tank disposed regularly by municipality } & $14(13 \%)$ \\
\hline & & & \multicolumn{3}{|c|}{ Discharged directly to a river/nullah/land } & $41(40 \%)$ \\
\hline & & & \multicolumn{3}{|l|}{ Others } & $1(1 \%)$ \\
\hline \multirow{2}{*}{\multicolumn{3}{|c|}{\begin{tabular}{llc|} 
Availability & of & Electricity \\
Yes $-102(99 \%)$ & No $-1(1 \%)$ \\
\end{tabular}}} & \multirow{2}{*}{\multicolumn{3}{|c|}{ Problems with Electricity }} & Yes $53(51 \%)$ \\
\hline & & & & & & No $49(49 \%)$ \\
\hline \multirow{2}{*}{\multicolumn{3}{|c|}{$\begin{array}{llll}\text { Problems } & \text { associated } & \text { with } & \text { Electricity } \\
\text { Supply } & & & \\
\end{array}$}} & \multirow{2}{*}{\begin{tabular}{|l|} 
Electiricity Cuts \\
$33(62 \%)$ \\
\end{tabular}} & \multicolumn{2}{|c|}{ Low + Changing voltage } & High Bill \\
\hline & & & & $19(36 \%)$ & & $1(2 \%)$ \\
\hline \multirow{2}{*}{$\begin{array}{l}\text { Ownership of } \\
\text { Assets }\end{array}$} & Television & Telephone & $\begin{array}{l}\text { Mobile } \\
\text { phone }\end{array}$ & $\begin{array}{l}\text { Computer/ } \\
\text { Laptop }\end{array}$ & $\begin{array}{l}\text { Scooter/ Motor } \\
\text { cycle/ Moped }\end{array}$ & Car/ Jeep/Van \\
\hline & $81(78.64 \%)$ & $10(9.71 \%)$ & $101(98.06 \%)$ & $5(4.85 \%)$ & $65(63.11 \%)$ & $0(0 \%)$ \\
\hline \multirow{2}{*}{\multicolumn{3}{|c|}{ Households having account in any Bank }} & \multicolumn{3}{|l|}{ Holders } & $94(91.26 \%)$ \\
\hline & & & \multicolumn{3}{|l|}{ Non-holders } & $9(8.74 \%)$ \\
\hline \multirow{2}{*}{\multicolumn{3}{|c|}{ Educational level of Household Heads }} & 1-4 Class & 5-8 Class & 9-12 Class & Graduate Level \\
\hline & & & $12(11.65 \%)$ & $28(27.18 \%)$ & $29(28.16 \%)$ & $34(33.01 \%)$ \\
\hline
\end{tabular}

\section{Rural Migration to Nagpur}

Table 1: Descriptive Statistics of Households

As Nagpur city being a tier II city, it is believed that many people from nearby villages migrate to Nagpur in search of their livelihood. The table 1 shows the number of households migrated to Nagpur for various purposes. It can be seen that $43 \%$ households are migrated to Nagpur for livelihood, out of which $2 \%$ households migrated for the purpose of children education, $35 \%$ households migrated to look for work and $6 \%$ households migrated to start new job. All those who have migrated are settled in Nagpur region. Thus, the unorganised sector is employing large number of migrated people from nearby villages who are coming in search of employment.

\section{Attributes Associated with Economic Development Perspectives}

The various attributes of economic development identified are Avg. Monthly Income, Secondary Occupation, Ownership status of house, Nature of House, No. of Household members Nature of Fuel Consumption, Holding account in bank, and Ownership of Assets (like television, telephone, mobile phone, PC/Laptop, Scooter/Motor cycle/Moped) as presented in table 1 . The table is self-explanatory and one can understand the associated problems faced by the labourers.

\section{Analysis of Perception towards Economic Development}

To know the perception of the households towards their economic status, the respondents were asked to give the opinion about how they perceive their economic status based on various attributes of economic development. The results are presented in fig 2 below:

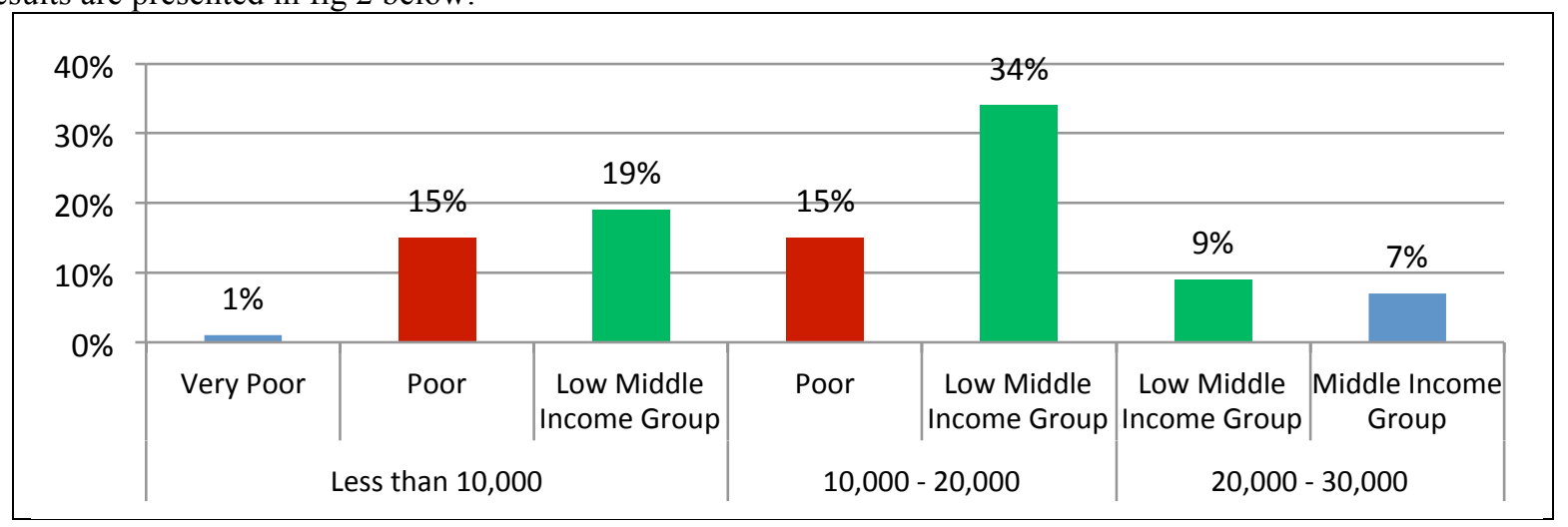

Fig 2: Perception of Household towards their Economic Status 
From the fig 2 , it can be observed that out of the total households, $1 \%$ households consider themselves as very poor, $15 \%$ consider themselves as poor and $19 \%$ households consider themselves as belonging to lower middle income group whose average monthly income is less than Rs. 10,000. Similarly, $15 \%$ households consider themselves as poor and $34 \%$ as belonging to lower middle income group whose income is between Rs 10,000-20,000; and 9\% households consider themselves as belonging to lower middle income group and $7 \%$ as middle income group households whose income is between Rs. 20,000-30,000. Thus, it can be inferred that households belonging to same income slabs have different perceptions towards their economic status, implying that these attributes which are different from income influences the perception towards economic status of the household.

\section{Regression Analysis to evaluate the Perception of Households towards Economic Status}

The above mentioned attributes of economic development analysed to know the significant attributes influencing the perception of households towards economic status. The dependent variable is perception towards the economic status and the various independent variables are; average monthly income, secondary occupation, house ownership status, nature of house, no. of household members, fuel consumption, holding account in bank, ownership of assets and education level of household member. The step-wise regression analysis is performed and the model is fitted to analyse the relationship and is presented as below:

\begin{tabular}{|c|c|c|c|c|c|}
\hline Multiple R & \multicolumn{5}{|l|}{0.630672621} \\
\hline R Square & \multicolumn{5}{|l|}{0.397747954} \\
\hline Adjusted R Square & \multicolumn{5}{|l|}{0.360107202} \\
\hline Standard Error & \multicolumn{5}{|l|}{0.471499618} \\
\hline Observations & \multicolumn{5}{|l|}{103} \\
\hline \multicolumn{6}{|c|}{ Analysis of Variance (ANOVA) } \\
\hline & $d f$ & $S S$ & $M S$ & $F$ & Significance $F$ \\
\hline Regression & 6 & 14.09495 & 2.349159 & 10.56695 & $5.54 \mathrm{E}-09$ \\
\hline Residual & 96 & 21.34194 & 0.222312 & & \\
\hline Total & 102 & 35.43689 & & & \\
\hline \multicolumn{6}{|c|}{ Stepwise Regression Results } \\
\hline & & Coefficients & Standard Error & $t$ Stat & P-value \\
\hline \multicolumn{2}{|l|}{ Intercept } & 2.1002891 & 0.36272 & 5.790395 & $8.85 \mathrm{E}-08$ \\
\hline \multicolumn{2}{|l|}{ Avg Monthly Income } & 0.3913036 & 0.06932 & 5.644903 & $1.67 \mathrm{E}-07 *$ \\
\hline \multicolumn{2}{|c|}{ Secondary Occupation } & -0.3285385 & 0.121632 & -2.7011 & $0.008171 *$ \\
\hline \multicolumn{2}{|l|}{ Fuel Consumption } & 0.2925989 & 0.119293 & 2.452771 & $0.015981 * *$ \\
\hline \multicolumn{2}{|c|}{ Holding account in bank } & 0.3329119 & 0.173821 & 1.91526 & $0.058436 * * *$ \\
\hline \multicolumn{2}{|l|}{ Mobile Phone (D3) } & -0.6603267 & 0.347939 & -1.89782 & $0.060724 * * *$ \\
\hline \multicolumn{2}{|c|}{ Scooter/Motor Cycle/ Moped (D5) } & 0.1880007 & 0.105586 & 1.780544 & $0.07815 * * *$ \\
\hline
\end{tabular}

Table 2: Regression Statistics - Factors affecting Perception of Household towards the Economic Status

From the table 2, it can be seen that the value of $\mathrm{R}^{2}$ (coefficient of determination) comes to be 0.3977 , which implies that the present factors (as listed in table above) explains $39.77 \%$ influence on the dependent variable, i.e., perception of households towards the economic status. As given in the ANOVA panel of regression output table, the value of $F$ statistics is 10.56695 and is significant at $1 \%$ level of significance as $p$ value is $<0.01$. Hence the regression model constructed fulfills the criteria of goodness of fit. Thus, the factors average monthly income, fuel consumption and secondary occupation are highly significant factors with $1 \%$ level of significance which determines the perception of households towards economic status, followed by the nature of fuel consumption which is significant at 5\% level of significance and holding account in bank and ownership of assets like mobile phones and scooter/motor cycle/moped are significant at $10 \%$ level of significance. Thus, it can be inferred that the households perception towards their economic status is influenced that average monthly income, secondary occupation, fuel consumption, holding account in bank and ownership of assets (mobile phones and scooter/motor cycle/moped). 


\section{Most Important Developmental Issues Perceived by the Labourers}

The respondents were asked to mention the four important development issues which needs to be addressed immediately for their development. The results are presented below in fig 3 .

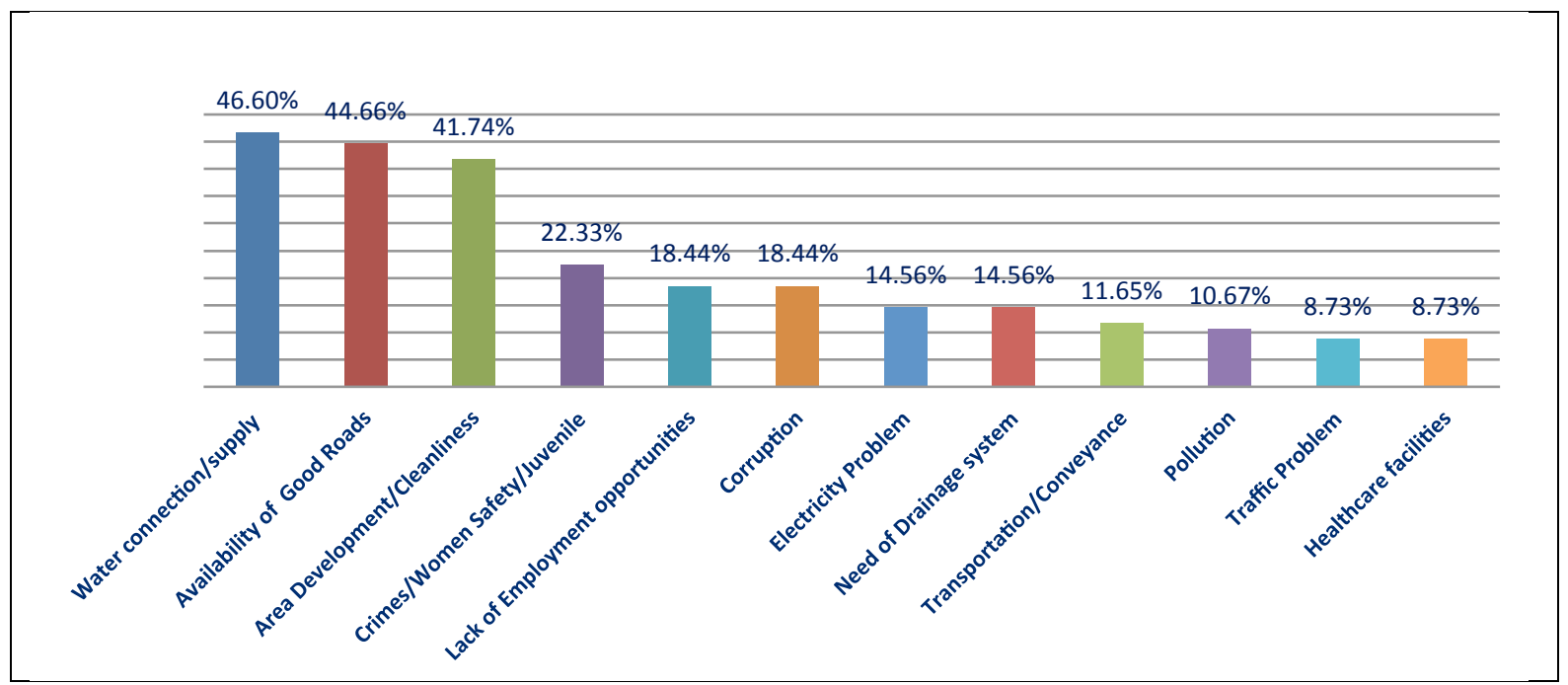

Fig 3: Most Important Development Issues that needs to be addressed

From fig 3, it can be seen that that tap water connectivity in the premises and regular water supply is the most important developmental need followed by availability of good roads in the areas, third important issues of development is overall area development with cleanliness, followed by better health and hygiene, crimes and issue of women safety, lack of employment opportunity and so on as given above. If these issues are addressed, it will indirectly contribute to make them available better employment opportunities and achieve overall economic development.

\section{Conclusion}

Nagpur being the tier II city, it represents many tier II cities in India. A lot of development activities and huge employment opportunities are rising for the rural migrants as well as local urban population in the city. The low income groups are finding the places of dwelling in slums of the city which lacks sanitation and civic amenities due to non-availability of proper shelter. The government has implemented several schemes and programmes to improve the living conditions of slum dwellers, viz., urban housing to envisage 'slum free India', rural development through all-weather road connectivity to villages, Pradhan mantri jan dhan yojana for financial inclusion or rural and urban poor, insurance schemes, skill development initiatives, pension schemes, swaccha bharat abhiyan for cleanliness, digital India to digitally empower nation, right to education, etc., and many more. But, there are several developmental issues associated with urban labourers in unorganised sector in Nagpur and various such cities which demand urgent action by the authorities. These are availability of good roads in slum and nearby areas, tap water facility in the houses, cleanliness and overall area development, control of crime and women safety, employment opportunities in formal (organized) sector, stable and continuous electricity supply, proper drainage system, transport/conveyance facilities, problem of pollution and traffic problem in many areas.

To conclude, if the above mentioned developmental needs are addressed immediately, it will lead to provide the urban labourers belonging to unorganised sector a better access to various benefits and better participation in economic activity. It will result into acquisition of various attributes which will not only influence their perception towards economic status but also lead to economic development in real sense through better economic participation.

\section{References}

1. Amartya Sen (2001), Development As Freedom, Oxford University Press.

2. Bhat J A \& Yadav P (2017), Economic Informal Sector and the Perspective of Informal Workers in India, Arts and Social Sciences Journal, January, Vol 8, Issue 1, p.n. 1-9.

3. Dogra Bharat (2014), Development Path of India - Some Major Policy Issues, Mainstream Weekly, Vol LII, No 9 February 22. (https://mainstreamweekly.net/article4750.html). 
4. Karn S. K, Shigeo Shikura and Harada Hideki (2003), Living Environment and Health of Urban poor: A study in Mumbai, Economic and Political Weekly, Vol 38, No 34, p.n.3575-3586.

5. National Commission For Enterprises in the Unorganised Sector (NCEUS) Report, The Challenge of Employment in India - An Informal Economy Perspective, April 2009.

(http://nceuis.nic.in/The_Challenge_of_Employment_in_India.pdf)

6. Ray Suresh (2016), Socio demographic conditions \& morbidity status of urban slum dwellers in Pune city, International Journal of Multidisciplinary Research and Development, Volume 3, Issue 6, June, p.n. 65-68.

7. Sarin A., Jain R. (2009), Effect of Mobile on Socio-economic Life of Urban Poor, Indian Institute of Management, W.P. No. 2009-02-05, February, p.n. 1-47.

(http://www.iimahd.ernet.in/publications/data/2009-02-05Sarin.pdf)

8. Sufaira C (2013), Socio Economic Conditions of Urban Slum Dwellers in Kannur Municipality, OSR Journal of Humanities and Social Science, Volume 10, Issue 5, May-Jun, p.n. 12-24. (http://iosrjournals.org/iosrjhss/papers/Vol10-issue5/C01051224.pdf?id=6240)

9. Zhang Yabei, Vanneman Reeve (2008), Economic Growth and the Environment: A Household Perspective from Cooking Fuel Choices and Indoor Air Pollution, March, p.n. 1-23. (http://paa2008.princeton.edu/papers/80097) 